\title{
Institutional abuse and societal silence: An emerging global problem
}

Warwick Middleton, Pam Stavropoulos, Martin J. Dorahy, Christa Krüger, Roberto

Lewis-Fernández, Alfonso Martínez-Taboas, Vedat Sar, Bethany Brand

Pam Stavropoulos, Ph.D.

Head of Research and Clinical Practice,

Adults Surviving Child Abuse,

Sydney, Australia,

pstavropoulos@iprimus.com.au.

Martin Dorahy, Ph.D.

Associate Professor,

Department of Psychology,

University of Canterbury,

New Zealand.

martin.dorahy@canterbury.ac.nz

Christa Krüger, M.D.

Professor,

Department of Psychiatry,

University of Pretoria,

South Africa.

Christa.Kruger@up.ac.za

Roberto Lewis-Fernández, M.D.

Professor,

Department of Psychiatry

Columbia University

New York State, USA

rlewis@nyspi.columbia.edu

Alfonso Martínez-Taboas, Ph.D.

Associate Professor,

Carlos Albizu University,

San Juan, Puerto Rico.

AMartínez@albizu.edu

Vedat Sar, M.D.

Professor,

Department of Psychiatry

Istanbul Faculty of Medicine

Istanbul University, Turkey.

President, European Society for Traumatic Stress Studies (ESTSS)

vsar@istanbul.edu.tr

Bethany Brand, Ph.D.

Professor of Psychology,

Towson University,

Maryland, USA,

BBrand@towson.edu

\section{Corresponding Author:}

Adjunct Professor Warwick Middleton 
MB BS, FRANZCP, MD.

Chair, The Cannan Institute,

Director, Trauma \& Dissociation Unit,

Belmont Hospital, Carina 4152

Direct correspondence to:-

Suite 4D, 87 Wickham Tce

Brisbane 4000

Ph: (07) 38314466

Fax: (07) 38314477

Mobile: 0417629813

Email: warmid@tpg.com.au

The Australian Royal Commission into Institutional Responses to Child Sexual Abuse was , announced by Australian Prime Minister, Julia Gillard, on 11 January 2013. In examining how institutions with a responsibility for, children "have managed and responded to allegations and instances of child sexual abuse and related matters" (Australian Government, 2013) it arguably represents the most wide-ranging attempt by any national government in history to examine the institutional processes (or lack thereof) for addressing of such abuse. Its frames of reference are very wide, including examining how institutions with a responsibility for children "have managed and responded to allegations and instances of child sexual abuse and related matters" (Australian Government, 2013). "The Commissioners can look at any private, public or non-governmental organisation that is, or was in the past involved with children, including government agencies, schools, sporting clubs, orphanages, foster care, and religious organisations. This includes where they consider an organisation caring for a child is responsible for the abuse or for not responding appropriately, regardless of where or when the abuse took place” (Australian Government, 2013).

The phenomena of individuals, or groups of individuals, associated with institutions using their roles to further their sexual abuse of children or to assist in the cover-up of such practices will necessarily be illuminated by the Royal Commission. When the national inquiry was announced, there were no less than three state-based inquiries dealing with child abuse planned or underway in Australia, one in Queensland, one in Victoria, and a just-announced inquiry in NSW. It is a testament to the enduring and tenacious use of power by those associated with societal institutions, that in a global sense, it has really only been within the last two decades that the world has witnessed progressive revelations involving many instances of individuals or groups from such institutions sexually abusing children. This is notwithstanding, a demonstrated palpable resistance on the part of the many institutions to cooperate in the uncovering of such crimes or the prosecution of those responsible.

Research demonstrates that approximately two thirds of both inpatients and outpatients in the mental health system report a history of childhood sexual and/or physical abuse (see Read et al., 2004 for extensive review). If emotional abuse and 
neglect are added to the mix, the percentage reporting an adverse/traumatic childhood becomes even higher. The Adverse Childhood Experiences (ACE) Study, a pioneering US epidemiological survey, has provided retrospective and prospective data from over 17,000 individuals regarding the effects of adverse events, including child abuse, during the first 18 years of life. This enormously significant ongoing study demonstrates the enduring, strongly proportionate, and frequently profound relationship between adverse childhood experiences and emotional states, disease burdens, high-risk sexual behaviour, self-destruction, drug abuse, health risks/healthcare costs, and early death, even decades later (Felitti and Anda, 2010). Furthermore, a recent detailed review found that child sexual abuse is intimately related to increased risk for poly-victimization, social stigmatization, and impaired attitudes toward the self and the social world (Olafson, 2011).

A sizeable proportion of victims with childhood abuse experiences present to medical and psychiatric systems and receive various diagnoses which do not necessarily refer to the traumatic origin of their illness. While research on dementia, schizophrenia, bipolar disorder, and depression is widely funded, grants are rarely given to study the mental health consequences of ongoing childhood trauma, which include dissociative disorders and complex trauma syndromes. Yet irrespective of the particular diagnosis, presence of childhood psychological trauma usually interferes with effective treatment unless it is psychotherapeutically addressed (Sar and Ross, 2006). The Australian Royal Commission has the potential to place at centre stage the frequently severe mental health consequences of a form of childhood trauma which affects large numbers of Australians and, by extension, to provide the impetus for the further development of mental health services that address both these individual and societal needs.

It is difficult to escape concluding that the single most pathogenic factor in the causation of mental illness is how we humans mistreat each other. Yet abuse of children is frequently perpetrated or overlooked by the professionals whose core roles emphasize the protection of children. These include teachers, health care professionals, police officers and judges as well as clergymen. Despite the lasting damage of childhood maltreatment, governments and societies have demonstrated an enduring reluctance to investigate how trauma and abuse contribute so substantially to filling our mental health centres, prisons, drug and alcohol services and medical wards.

Partially and belatedly, society is attempting something that has never before been achieved - progressive exposure to public gaze of traumas that, despite earlier attempts to foster their recognition, have returned to or remained in darkness. In 1962, Kempe et al. described the "battered child" syndrome. By the 1970's society was beginning to grapple with the mental health syndromes of Vietnam Veterans, whilst at the same time feminist writers and researchers were challenging decades-old rationalisations about Oedipal phantasies and hysterical mendacity. In 1981 Judith Herman published "Father-Daughter Incest”. In 1986 Russell published "The Secret Trauma: Incest in the Lives of Girls and Women", a large epidemiological study on incest and other childhood sexual abuse. Russell's study suggested 16\% of American females had been incestuously abused, $4.5 \%$ by their fathers. 
Society's confrontation with the extent of child abuse has been furthered by the documentation of abuses perpetrated in state or church institutions, as well as by evidence of violations of sexual boundaries by health professionals. In Australia, as elsewhere, there is increasing recognition of the complex syndromes that arise from severe and ongoing childhood abuse (e.g. Middleton 2013 a and b; Middleton and Butler, 1998; Kezelman and Stavropoulos, 2012).

It needs to be emphasized that child sexual abuse occurs in any circumstance in which it can occur, and that broadly speaking it is unsafe to assume that it won't occur. Holding the religious position of priest or brother is a calling that happens to afford particular opportunities to abuse children sexually. Such individuals carry the mystique of being the living representatives of God, are aligned with a rich and powerful global organization, and occupy positions of power and authority that extend not only to children in their care, but to the children's trusting parents and the wider community.

Children located in closed hierarchal systems, such as orphanages or juvenile justice centers, are in particular danger of sexual abuse. While egregious sexual abuse is found within churches, state orphanages, sporting clubs, scouting groups and the like, sadly most such cases arise within families, as borne out in abuse profiles contained in case series of patients with dissociative identity disorder (e.g., Middleton and Butler, 1998). The majority of ongoing child sexual abuse within our society is incestuous.

There is in society a parallel universe that is very close. All of us, whether knowingly or unknowingly, have frequent contact with it. It is populated by individuals who outwardly appear to be respectable, law abiding, and not infrequently influential, and even popular members of society. They are found in all professions and they sexually abuse children, some in ways that are almost unimaginably extreme. Whilst Josef Fritzl was portrayed in 2008 as some sort of unfathomable "monster" who imprisoned his daughter in an underground "dungeon" for 24 years (where she produced seven incestuously fathered children), a close reading of the English-language press reports of the last six years demonstrates at least 51 reported cases of ongoing incestuous abuse during adulthood and/or multigenerational incestuous abuse from a total of 25 countries. In some cases it extended for longer than the 31 years Elisabeth Fritzl endured, and in some it produced more pregnancies and children (see Middleton, 2013 a \& b).

A key consideration for the Australian Royal Commission is the mechanisms by which prominent and institutionally connected individuals can repeatedly adapt the systems of their workplaces in order to sexually abuse children for decades. British media personality Jimmy Savile perpetrated his sexual abuses for at least 54 years. It also appears that there were in excess of 450 victims. Yet Savile (who had a longterm association with the BBC) maintained a close relationship with Prince Charles, cultivated an image of a tireless charity worker, and had friendships with senior members of the British government. He also managed to avoid any serious investigation of his crimes during his lifetime, despite the fact that many who worked with him were aware of his paedophilia (Brown, 2013). British Prime Minister David Cameron, speaking in the House of Commons on October 24, 2012, posed the perplexing question, “How did he get away with it for so long?” (London 24, 2012). 
Operation Yewtree, the police investigation prompted by the child sexual abuse allegations against Savile, took on particular significance for Australia when the iconic 83-year old entertainer, Rolf Harris, became the fourth individual arrested. In late August 2013 it was announced that Harris had been charged with nine counts of alleged indecent assault involving two different teenage girls in 1980-81 and 1986, as well as four of making indecent images of a child, allegedly occurring in 2012 (Gearin, 2013).

In the United States, Jerry Sandusky served as assistant coach of Pennsylvania State University's famous football team from 1969 to 1999. In 1977 Sandusky established 'The Second Mile', a non-profit charity serving underprivileged and at-risk youth. Sandusky often met his young victims through his work at 'The Second Mile' (whose motto is "Providing Children With Help and Hope"). In 2011, he was arrested and charged with 52 counts of sexual abuse over a 15-year period. In June 2012 he was found guilty on 45 charges relating to the sexual abuse of ten boys and sentenced to 30 to 60 years in prison. Somehow his behavior within this prestigious institution escaped scrutiny for many years (Huffington Post, 2013).

Any Royal Commission has to be aware that the parallel world of outwardly respectable and at times powerful abusers, such as those named in the NSW Wood Royal Commission in the late 90's, can contain close business, religious, and political associates. International experience makes it very clear that such politically connected individuals - who have everything to lose by an open inquiry into the activities of their networks - can exert enormous power. They can markedly limit, or even effectively destroy, an investigation which aims to expose their activities.

A prominent example of the extent to which attempted cover-up can go is what has become known as 'the Franklin Scandal' in the United States. In this case, politically vested interests subverted the state police, elements of the CIA and FBI, the judiciary, and the press. The Nebraska State Legislature had so little confidence in the FBI investigation of a national paedophile ring closely associated with the influential and corrupt Republican, Lawrence King, in Omaha, Nebraska, and the Washington lobbyist, Craig Spence, that they commissioned their own investigation. The State's chief investigator, Gary Caradori, died (along with his son) when his light plane disintegrated and crashed into a cornfield near Aston, Illinois on July 11, 1990. Caradori's briefcase, which was thought to contain vital evidence, was not recovered from the crash site, nor were the plane's rear seats, the likeliest site for a bomb. His death in such circumstances effectively ended the Nebraska investigation, as additional witnesses were then too frightened to come forward. King, jailed for embezzling \$40 million, had a \$1 million civil settlement against him awarded in favor of a victim, Paul Bonacci, but has never been charged with sex offences (Bryant, 2009).

While there are some who will consign accounts of politically connected organized abuse, such as "the Franklin Scandal", to the category of "conspiracy theory", the reality is that our world is being progressively acquainted with the fact that such examples are repeatedly surfacing. In October 1996, 300,000 citizens staged a march through the streets of Brussels to protest the enormously bungled police investigation into the crimes of Marc Dutroux, a serial killer and paedophile who many suspected was part of a sex ring whose members included high-ranking members of the police force and government. Jean-Marc Connerotte, who was the original presiding judge in 
the case, broke down in tears in the witness stand when he described "the bullet-proof vehicles and armed guards needed to protect him against the shadowy figures determined to stop the full truth coming out". He went on to state, "Never before in Belgium has an investigating judge at the service of the king been subjected to such pressure. We were told by police that [murder] contracts had been taken out against magistrates” (Evans-Pritchard, 2004).

In September 2010 Carlos Cruz (a famous Portuguese television presenter), Manuel Abrantes (former Casa Pia governor), and Jorge Ritto (former UNESCO ambassador) were among six individuals finally convicted in respect to the activities of a politically connected Portuguese paedophile ring that had operated for decades (BBC, 2010). Another long running scandal, with a similar alleged political connection, has been centered on the Haut de la Garenne children's home in Jersey. One of the visitors to the home was Jimmy Savile (Halliday et al., 2012).

In December 2012 the Argentine President, Christina Kircher, was among the political leaders who publicly expressed anger following the Tucumán court acquittal of 13 defendants accused of trafficking women. There was associated outrage and widespread protest across Argentina. Susan Trimarco, whose daughter vanished at the age of 23, had carried out a relentless search which exposed an underworld of organized crime, and which included individuals who were operating brothels with protection afforded by authorities across the country (Aljazeera, 2012).

For all of history, children have been exploited and sexually abused. This is not only within families, but frequently by those who work within institutions and who have had the power or influence to achieve effective immunity from prosecution. There was never some "golden age" in which children were generally better treated (DeMause, 2002). As the full extent of institutional complicity in the sexual abuse of children becomes uncomfortably more obvious, it does not signify that we are falling into an abyss. Rather it suggests that for the first time in our history, such issues have reached a point at which they have attained such significance that they have become the subject of a wide-ranging national royal commission.

\section{References:}

Aljazeera (2012, December 13). Outrage over Argentina sex slavery acquittals. Retrieved from http://tinyurl.com/aseugz9 on 01-09-13.

Australian Government (2013) Royal Commission into institutional responses to child sexual abuse. Retrieved from http://tinyurl.com/pxurb74 on 01-09-13.

BBC (2010, September 3). Six men jailed for Portugal child sex abuse. Retrieved from http://tinyurl.com/2dzxupu on 01-09-13.

Bolen RM (2001) Child Sexual Abuse: Its Scope and Our Failure. New York: Kluwer.

Brown J (2013) Jimmy Savile: A report that reveals 54 years of abuse by the man who groomed the nation. The Independent, 12 January. Retrieved from http://tiny.cc/2nrosw on 09-02-13.

Bryant N (2009) The Franklin Scandal. Walterville OR: Trineday. 
DeMause L (2002) The emotional life of nations. New York: Institute of Psychohistory.

Evans-Pritchard A (2004) Jury tells of murder plots to block Dutroux investigation. The Telegraph, 5 March. Retrieved from http://tinyurl.com/kcylxdt on 08-09-13.

Felitti VJ and Anda RF (2010) The Relationship of Adverse Childhood Experiences to Adult Medical Disease, Psychiatric Disorders and Sexual Behavior: Implications for Healthcare. Ch. 8 in Lanius RA, Vermetten E and Pain C. The Impact of Early Life Trauma on Health and Disease. Cambridge University Press, pp.77-87.

Gearin M (2013) Rolf Harris charged with indecent assault and making indecent images of a child. ABC News, 30 August. Retrieved from http://tinyurl.com/q7dgel7 on 02-09-13.

Halliday J, Viner K \& O’Carroll L (2012) Jimmy Savile linked with Haut de la Garenne children's home scandal. The Guardian 9 October. Retrieved from http://tinyurl.com/8n66syd on 01-09-13.

Herman J (1981) Father Daughter Incest. New York: Basic Books.

Herman J (1992) Trauma and Recovery: the aftermath of violence - from domestic abuse to political terror. New York: Basic Books.

Huffington Post (2013) Penn State Freeh report: Reactions to the investigation. Huffington Post, $12^{\text {th }}$ July. Retrieved from http://tinyurl.com/n7oybqk on 21-07-13.

Kempe CH, Silverman FN, Droegemuller W and Silver HK (1962) The battered child syndrome. Journal of the American Medical Association; 181, 17-24.

Kezelman C and Stavropoulos (2012) 'The Last Frontier': Practice Guidelines for Complex Trauma and Trauma - Informed Care and Service Delivery, Compiled and Published by Adults Surviving Child Abuse (ASCA). Available from: $\underline{\text { http://tiny.cc/1urosw }}$

London 24 (2012) David Cameron reveals Jimmy Savile allegations to be investigated by Director of Public Prosecutions Keir Stamer. London, 24 October. Retrieved from http://tiny.cc/27rosw on 09-02-13.

McKenzie N. Baker R and Lee J (2012) Church’s suicide victims. The Age, 13 April. Retrieved from http://tiny.cc/cgsosw on 26-01-13.

Middleton W and Butler (1998) Dissociative identity disorder; an Australian series. Australian \& New Zealand Journal of Psychiatry, 32: 794-804.

Middleton W (2013a) Parent-child incest that extends into adulthood: A survey of international press reports, 2007-2011. Journal of Trauma and Dissociation. 14: 184197.

Middleton W (2013b) Ongoing incestuous abuse during adulthood. Journal of Trauma and Dissociation, 14: 251-272. 
Olafson E (2011) Child sexual abuse: Demography, impact, and interventions. Journal of Child and Adolescent Trauma, 4: 8-21.

Read J, Goodman L, Morrison AP, et al. (2004) Childhood trauma, loss and stress. In: Read J, Mosher LR, Bentall R, eds. Models of Madness. Hove, East Sussex: BrunnerRoutledge; 223-252.

Russell DEH (1986) The Secret Trauma: Incest in the Lives of Girls and Women. New York: Basic Books.

Sar V and Ross CA (2006) Dissociative disorders as a confounding factor in psychiatric research. Psychiatric Clinics of North America, 29: 129-144. 